\title{
Theoretical study of the formation mechanism of molecules CaF for fluoride determination using electrothermal molecular absorption spectrometry
}

\author{
Polina V. Zaitceva*, Alexander A. Pupyshev \\ Ural Federal University named after the first President of Russia B.N.Yeltsin (UrFU), \\ ul. Mira, 19, Ekaterinburg, 620002, Russian Federation
}

*Corresponding author: Polina Zaitceva, E-mail: zaitcevapolina@gmail.com

Submitted 15 January 2016

\begin{abstract}
In order to select the temperature-time heating program, the calibration method, the prediction of matrix interference and to increase the sensitivity and accuracy of the halogens determination using the electrothermal molecular absorption spectrometry it is essential to know the formation mechanism of the measured molecules. Thermochemical processes of gaseous molecules $\mathrm{CaF}$ formation, which are used in the electrothermal molecular absorption determination of fluorine, were studied using the method of the thermodynamic simulation. All calculations were performed using the HSC 6.1 software package with its own database of thermodynamic data. For calculations, the non-equilibrium thermodynamic system, which was realized in the graphite furnace, was divided into the thermodynamic subsystems that correspond to the main stages of time-temperature program: drying of the sample, pyrolysis, vaporization and formation of gaseous diatomic molecules. The composition of the condensed sample residues after drying and pyrolysis stages, the composition of the gas phase in the analytical zone of the graphite furnace during vaporization and the formation of molecules stages were determined by the calculations. This study theoretically describes thermochemical processes of the formation of gaseous $\mathrm{CaF}$ molecules using thermodynamic simulation for electrothermal molecular absorption determination of fluorine. The calculations make it possible to establish that gaseous molecules $\mathrm{CaF}^{9}$ are formed during the course of the thermal decomposition of the condensed fluoride $\left(\mathrm{CaF}_{2}{ }^{\mathrm{c}}\right)$. The correct execution of thermodynamic simulation was confirmed by the comparison of the theoretical temperature curves of pyrolysis and the formation of molecules $\mathrm{CaF}^{\mathrm{g}}$ with the experimental curves. The developed procedure of the thermodynamic simulation can be applied to study the formation of other dimeric molecules used for molecular absorption analysis with electrothermal atomization.

Keywords: high-resolution continuum source molecular absorption spectrometry, thermodynamic simulation, fluorine, calcium mono-fluoride, temperature of drying, pyrolysis and vaporization.
\end{abstract}

\section{Теоретическое изучение механизмов образования молекул CaF при электротермическом молекулярно- абсорбционном определении фтора}

\author{
П.В. Зайцева*, А.А. Пупышев \\ Уральский федеральный университет имени первого Президента России Б.Н. Ельцина (УрФУ), \\ Российская Федерация, 620002, г. Екатеринбург, ул. Мира, д. 19
}

*Адрес для переписки: Зайцева Полина Владимировна, E-mail: zaitcevapolina@gmail.com

Поступила в редакцию 15 января 2016 г.

Методом равновесного термодинамического моделирования изучены термохимические процессы образования газообразных молекул $\mathrm{CaF}^{9}$ при электротермическом молекулярно-абсорбционном определения фтора. Расчет выполнен с помощью программного комплекса HSC 6.1 с собственной базой термодинамических данных. Для проведения расчетов неравновесную 
термодинамическую систему, реализуемую в графитовой печи, разбивали на последовательные термодинамические подсистемы, которые соответствуют основным стадиям температурно-временной программы: высушивание пробы, пиролиз, испарение и образования газообразных двухатомных молекул. Расчетным путем определен состав конденсированных остатков пробы после стадий высушивания и пиролиза, состав газовой фазы аналитической зоны графитовой печи на стадии испарения и образования молекул. Проведенные расчеты позволили установить, что образование газообразных молекул $\mathrm{CaF}^{\mathrm{g}}$ происходит в результате термического разложения конденсированного фторида кальция $\mathrm{CaF}_{2}$. Правильность выполненного термодинамического моделирования подтверждена сопоставлением теоретических температурных кривых пиролиза и образования молекул $\mathrm{CaF}^{g}$ с экспериментальными. Предложенный алгоритм термодинамического моделирования может быть использован для изучения образования других димерных молекул, используемых для молекулярно-абсорбционного анализа с электротермической атомизацией. Результаты моделирования полезны для выбора температурно-временной программы нагрева, способа градуирования, изучения матричных помех, повышения чувствительности и точности определения галогенов.

Ключевые слова: молекулярно-абсорбционная спектрометрия, электротермическая атомизация, термодинамическое моделирование, фтор, фторид кальция, температура стадии высушивания, пиролиза и испарения.

\section{Introduction}

The occurrence of high resolution continuum source atomic absorption spectrophotometers (HR CS AAS) made possible the determination of halogens, sulfur, and phosphorus by the absorption spectra of their diatomic molecules [1]. Simultaneously, there was a question about the formation mechanism of these molecules in commonly used atomizers [2]. Knowledge of this mechanism and the possibility of its control can significantly affect the achievable detection limits and range of determined elements concentrations, calibration method, matrix interference, accuracy, etc.

The experimental method for studying the formation mechanism of $\mathrm{SrF}^{9}$ molecules in the graphite furnace using mixed and separate injection of molecule forming element and the analyte in graphite furnace was proposed in [2]. However, at the present time this experimental method has limited possibilities for investigations. Therefore, more flexible and informative theoretical method and study procedure of SrF molecule formation using the method of equilibrium thermodynamic simulation was proposed in [3]. Control of the developed simulation procedure was carried out based on the experimental results $[2,4]$ and own experimental investigation. The aim of this work was to use the developed simulation procedure to study the formation mechanism of diatomic $\mathrm{CaF}$ molecules for electrothermal atomic absorption determination of fluorine.

\section{Calculation procedure of thermodynamic simulation}

The method of the equilibrium thermodynamic simulation consists of the behavior analysis of high-temperature heterogeneous multicomponent system based on the calculation of its full equilibrium chemical composition $[5,6]$. The calculation is performed at the ex- tremum of the thermodynamic potential (entropy maximization or free-energy (Gibbs energy) minimization) taking into account most of the possible components in the equilibrium. The ability to apply the equilibrium thermodynamic simulation to the study of thermochemical processes of elements atomization in the graphite furnace, which is a non-equilibrium opened thermodynamic system, has been well founded and confirmed in [4, 7]. For the calculations, it was suggested to use the approach based on the division of a non-equilibrium system into the successive quasi-equilibrium subsystems corresponding to the sequence of thermal transformations of the initial sample: drying, pyrolysis, vaporization. The resulting calculated condensed equilibrium chemical composition of the previous subsystem is the starting compound for the subsequent subsystem. This approach takes into account the interaction between all of the components of the system (solvent, sample matrix, analyte, chemical agent - modifier, surface material of the atomizer, protective or active gas with its impurity composition), distillation of volatile components, allows for the determination of the complete chemical composition and the optimal temperature for each stage of atomization, etc.

Procedure of the thermochemical processes simulation for molecular absorption analysis in the graphite furnace and corresponding basic stages of the time-temperature program of the electrothermal atomizer includes the following sequence [3].

The stage of sample drying. Initial chemical composition of the thermodynamic subsystem corresponds to experimental or suggested data: diluent and salt composition of the pipetted solution. The amount of argon in the subsystem is set based on the molar ratio of $A r$ : solvent $=1: 1$. The interaction of the sample solution with carbon atomizer is excluded. Calculations take into account the gaseous and condensed phase, 
considering the individual condensed and water compounds in the latter. The calculation is performed in the $30-150^{\circ} \mathrm{C}$ temperature range with the step of $10^{\circ} \mathrm{C}$, taking into account losses of the gaseous products in an open system of the atomizer at each step.

The stage of pyrolysis. Initial chemical composition of the thermodynamic subsystem for this stage is determined by the calculated composition of the condensed product of the previous drying stage under experimental or selected temperature of this step. In calculations a "thick" layer of the sample is divided into two zones: in contact and not in contact with the carbon atomizer. All sample components in these zones are uniformly distributed and may form, by reaction between each other, condensed individual substances and condensed dilute solutions (usually - oxides) based on the sample matrix and chemical agent - modifier. The molar ratio of carbon : sample matrix is assumed to be equal to 10, Ar: condensed sample $=10^{3}-10^{4}$. The calculation is carried out in the range of temperature of the drying stage up to $2000^{\circ} \mathrm{C}$ with the steps of $50^{\circ} \mathrm{C}$, taking into account at each step the loss of gaseous products in an open atomizer system.

The stage of vaporization and formation molecules. This step, which is realized experimentally at the maximum heating rate of the graphite furnace and the gas stop mode ("gas-stop") for calculations, is subdivided into two successive stages.

The first stage - vaporization. Initial chemical composition of the condensed products on the surface of the atomizer for this phase is determined by summing up the calculated compositions of condensed products of the two zones of the sample during the pyrolysis stage at experimental or theoretical temperature of this step (corresponding to the loss of analyte in the gas phase of the graphite furnace). Further calculations are carried out only for a "thin" layer of the sample undivided into zones and reacting with the carbon of the atomizer. This is because most of the volatile components of the sample during the pyrolysis stage have been removed from the space of the graphite furnace by argon flow. The amount of argon for the vaporization stage is set to be equal to the device placed in graphite furnace at an appropriate temperature stage. The calculation is carried out in the temperature range from the temperature of the pyrolysis stage to the temperature of complete vaporization of the analyte with step $100^{\circ} \mathrm{C}$. The amount and chemical form of the condensed residue sample components (analyte and sample matrix), passing into the gas phase of the furnace, is determined at each step of the calculation.

The second stage - the arrival of gaseous components of the sample into the analytical zone of thoroughly warmed graphite furnace. Here, only the gas phase of the graphite atomizer is examined, which is not in equilibrium with the condensed residue of the sample on its surface. Initial chemical composition of the gas phase is determined by the gaseous products that leave the condensed residue of the sample at an appropriate temperature of the vaporization stage, by argon placed in graphite furnace at this temperature, by its impurities $\left(\mathrm{O}_{2}, \mathrm{~N}_{2}, \mathrm{H}_{2} \mathrm{O}\right)$ and partial pressure of carbon vapor in the gaseous phase of the furnace. This calculation is performed completely analogous to the calculation of the atomization element stage [7] and carried out starting from the temperature of the pyrolysis step up to $2700^{\circ} \mathrm{C}$ with step of $50^{\circ} \mathrm{C}$.

When applying the components of the sample to different portions of the evaporator surface for the drying and pyrolysis stage, as well as for the vaporization step, calculations are performed individually for each of the initial chemical composition. When calculating the chemical composition of the gas phase of the graphite furnace only the possibility of partial mixing and interaction of the vaporized components is taken into account.

\section{Results and discussion}

The procedure of thermodynamic simulation, which we developed in [3], was used for studying of the formation mechanism of $\mathrm{CaF}$ molecules in the graphite furnace. The applicability verification of this procedure was carried out using experimental results from [8-10], where the possibility of fluorine determination from the molecular absorption CaF using electrothermal vaporization was studied.

For the thermodynamic simulation the initial compositions of thermodynamic systems that were used are completely similar to the experimental data of [8] where fluorine was introduced as $\mathrm{NaF}$ and $\mathrm{Ca}\left(\mathrm{NO}_{3}\right)_{2}$ was used as chemical agent (10 $\mathrm{ng}$ of fluorine, $40 \mu \mathrm{g}$ of calcium, $20 \mu \mathrm{L} \mathrm{H}{ }_{2} \mathrm{O}$ ), [9] (3 $\mathrm{ng}$ of fluorine, $15 \mu \mathrm{g}$ of calcium, 20 $\mu \mathrm{L} \mathrm{H}_{2} \mathrm{O}$ ) and [10] (16 $\mathrm{ng}$ of fluorine, $315 \mu \mathrm{g}$ of calcium, $20 \mu \mathrm{L} \mathrm{H}_{2} \mathrm{O}$ ). Calculations were carried out in full compliance with the procedure mentioned in paragraph above. Considered in the calculations of the thermodynamic equilibrium individual substances are given Table. All calculations were performed using the HSC 6.1 software package (minimization of Gibbs energy in thermodynamic system) [11] with its own database.

\section{The stage of sample drying}

The calculation results of the equilibrium composition of the system Ca-F-Na-O-H-Ar at the drying stage using the experimental data in [8] are shown in Fig. 1. It is observed that the exchange reactions during the formation of $\mathrm{CaF}_{2}{ }^{\mathrm{c}}$ are already possible at the heating of the solutions on the graphite platform during the stage of sample drying. With the low-temper- 
Individual substances taken into account in the calculations

\begin{tabular}{|c|c|c|}
\hline $\begin{array}{c}\text { Gas } \\
\text { (upper index }-\mathrm{g} \text { ) }\end{array}$ & $\begin{array}{c}\text { Condensed } \\
\text { (upper index -c) }\end{array}$ & $\begin{array}{c}\text { Aqueous } \\
\text { (upper index -a) }\end{array}$ \\
\hline $\mathrm{Ar}$ & - & \\
\hline $\mathrm{C}, \mathrm{C}_{2}, \mathrm{C}_{3}, \mathrm{C}_{4}, \mathrm{C}_{5}, \mathrm{CO}, \mathrm{CO}_{2}, \mathrm{C}_{2} \mathrm{O}, \mathrm{C}_{3} \mathrm{O}_{2}$ & C & \\
\hline $\begin{array}{c}\mathrm{Ca}, \mathrm{Ca}_{2}, \mathrm{CaF}, \mathrm{CaF}_{2}, \mathrm{CaF}(\mathrm{OH}), \mathrm{CaH}, \mathrm{CaO}, \\
\mathrm{CaOH}, \mathrm{Ca}(\mathrm{OH})_{2}\end{array}$ & $\begin{array}{c}\mathrm{Ca}, \mathrm{CaC}_{2}, \mathrm{CaCO}_{3}, \mathrm{CaF}_{2}, \mathrm{CaH}_{2}, \mathrm{Ca}\left(\mathrm{NO}_{3}\right)_{2} \\
\mathrm{Ca}\left(\mathrm{NO}_{3}\right)_{2} \cdot 2 \mathrm{H}_{2} \mathrm{O}, \mathrm{Ca}\left(\mathrm{NO}_{3}\right)_{2} \cdot 3 \mathrm{H}_{2} \mathrm{O} \\
\mathrm{Ca}\left(\mathrm{NO}_{3}\right)_{2} \cdot 4 \mathrm{H}_{2} \mathrm{O}, \mathrm{CaO}, \mathrm{CaO}_{2}, \mathrm{Ca}(\mathrm{OH})_{2}\end{array}$ & \\
\hline
\end{tabular}

$\mathrm{F}, \mathrm{F}_{2}, \mathrm{FOO}, \mathrm{FNO}, \mathrm{FNO}_{2}, \mathrm{FNO}_{3}, \mathrm{~F}_{3} \mathrm{NO}, \mathrm{CF}, \mathrm{CF}_{2}$, $\mathrm{CF}_{3}, \mathrm{CF}_{4}, \mathrm{C}_{2} \mathrm{~F}, \mathrm{C}_{2} \mathrm{~F}_{2}, \mathrm{C}_{2} \mathrm{~F}_{3}, \mathrm{C}_{2} \mathrm{~F}_{4}, \mathrm{C}_{2} \mathrm{~F}_{5}, \mathrm{C}_{2} \mathrm{~F}_{6}, \mathrm{C}_{3} \mathrm{~F}_{7}$, $\mathrm{C}_{4} \mathrm{~F}_{8}, \mathrm{C}_{4} \mathrm{~F}_{10}, \mathrm{C}_{6} \mathrm{~F}_{6}, \mathrm{C}_{7} \mathrm{~F}_{8}, \mathrm{COF}, \mathrm{COF}_{2}, \mathrm{HF}, \mathrm{H}_{2} \mathrm{~F}_{2}$, $\mathrm{H}_{3} \mathrm{~F}_{3}, \mathrm{H}_{4} \mathrm{~F}_{4}, \mathrm{H}_{5} \mathrm{~F}_{5}, \mathrm{H}_{6} \mathrm{~F}_{6}, \mathrm{H}_{7} \mathrm{~F}_{7}, \mathrm{HOF}, \mathrm{NF}, \mathrm{NF}_{2}, \mathrm{NF}_{3}$, $\mathrm{NH}_{4} \mathrm{~F}, \mathrm{NH}_{4} \mathrm{HF}_{2}, \mathrm{NaF}, \mathrm{NaF} \cdot 2 \mathrm{HF}, \mathrm{NaHF}_{2}$ $\mathrm{HF}, \mathrm{NaF}, \mathrm{NF}_{3}$ $\mathrm{N}_{2} \mathrm{~F}_{2}, \mathrm{~N}_{2} \mathrm{~F}_{4}, \mathrm{NF}_{3} \mathrm{O}, \mathrm{NHF}, \mathrm{NHF}_{2}, \mathrm{NH}_{2} \mathrm{~F}, \mathrm{NOF}, \mathrm{NaF}$, $\mathrm{Na}_{2} \mathrm{~F}_{2}, \mathrm{Na}_{3} \mathrm{~F}_{3}, \mathrm{OF}, \mathrm{OF}_{2}, \mathrm{O}_{2} \mathrm{~F}, \mathrm{O}_{2} \mathrm{~F}_{2}$, OFO

\begin{tabular}{ccc}
\hline $\mathrm{H}, \mathrm{H}_{2}, \mathrm{OH}, \mathrm{HO}_{2}, \mathrm{H}_{2} \mathrm{O}, \mathrm{H}_{2} \mathrm{O}_{2}$ & $\mathrm{H}_{2} \mathrm{O}$ & $\mathrm{H}_{2}, \mathrm{OH}, \mathrm{H}_{2} \mathrm{O}$ \\
\hline $\mathrm{N}, \mathrm{N}_{2}, \mathrm{~N}_{3}, \mathrm{NH}, \mathrm{NH}_{2}, \mathrm{NH}_{3}, \mathrm{HN}_{3}, \mathrm{~N}_{2} \mathrm{H}_{2}, \mathrm{~N}_{2} \mathrm{H}_{4}, \mathrm{~N}_{3} \mathrm{H}$, & $\mathrm{HNO}_{3}, \mathrm{NH}_{4} \mathrm{~N}_{3}, \mathrm{NH}_{4} \mathrm{NO}_{3}, \mathrm{NH}_{4} \mathrm{OH}, \mathrm{N}_{2} \mathrm{O}_{4}$, & $\mathrm{N}_{2}, \mathrm{NH}_{3}, \mathrm{~N}_{2} \mathrm{H}_{4}, \mathrm{~N}_{3} \mathrm{H}_{1}, \mathrm{HN}_{3}$, \\
$\mathrm{N}_{2} \mathrm{H}_{4} \cdot \mathrm{H}_{2} \mathrm{O}, \mathrm{NH}_{2} \mathrm{NO}_{2}, \mathrm{NH}_{2} \mathrm{OH}, \mathrm{HNO}, \mathrm{NH}_{2} \mathrm{OH}, \mathrm{HNO}_{2}$, \\
$\mathrm{NO}, \mathrm{NO}_{2}, \mathrm{NO}_{3}, \mathrm{~N}_{2} \mathrm{O}, \mathrm{N}_{2} \mathrm{O}_{2}, \mathrm{~N}_{2} \mathrm{O}_{3}, \mathrm{~N}_{2} \mathrm{O}_{4}, \mathrm{~N}_{2} \mathrm{O}_{5}$ & $\mathrm{~N}_{2} \mathrm{O}_{5}$ & $\mathrm{HNO}_{3}, \mathrm{~N}_{2} \mathrm{H}_{5} \mathrm{OH}_{2} \mathrm{~N}_{2} \mathrm{H}_{5} \mathrm{NO}_{3}$ \\
\hline
\end{tabular}

$\mathrm{Na}, \mathrm{Na}_{2}, \mathrm{NaH}, \mathrm{NaOH}, \mathrm{Na}_{2} \mathrm{O}_{2} \mathrm{H}_{2}, \mathrm{NaNO}_{2}, \mathrm{NaNO}_{3}$, $\mathrm{NaO}, \mathrm{Na}_{2} \mathrm{O}, \mathrm{Na}_{2} \mathrm{O}_{2}$ $\mathrm{Na}, \mathrm{NaH}, \mathrm{NaOH}, \mathrm{NaOH} \cdot \mathrm{H}_{2} \mathrm{O}, \mathrm{NaN}_{3}$, $\mathrm{NaNH}_{2}, \mathrm{NaNH}_{3}, \mathrm{NaNO}_{2}, \mathrm{NaNO}_{3}, \mathrm{NaO}_{2}, \quad \mathrm{NaOH}$, $\mathrm{O}, \mathrm{O}_{2}, \mathrm{O}_{3}$ $\mathrm{Na}_{2} \mathrm{O}, \mathrm{Na}_{2} \mathrm{O}_{2}$

\begin{tabular}{ccc}
\hline $\mathrm{O}_{2}, \mathrm{O}_{3}$ & - & $\mathrm{O}_{2}, \mathrm{O}_{2}, \mathrm{O}_{3}$ \\
\hline
\end{tabular}
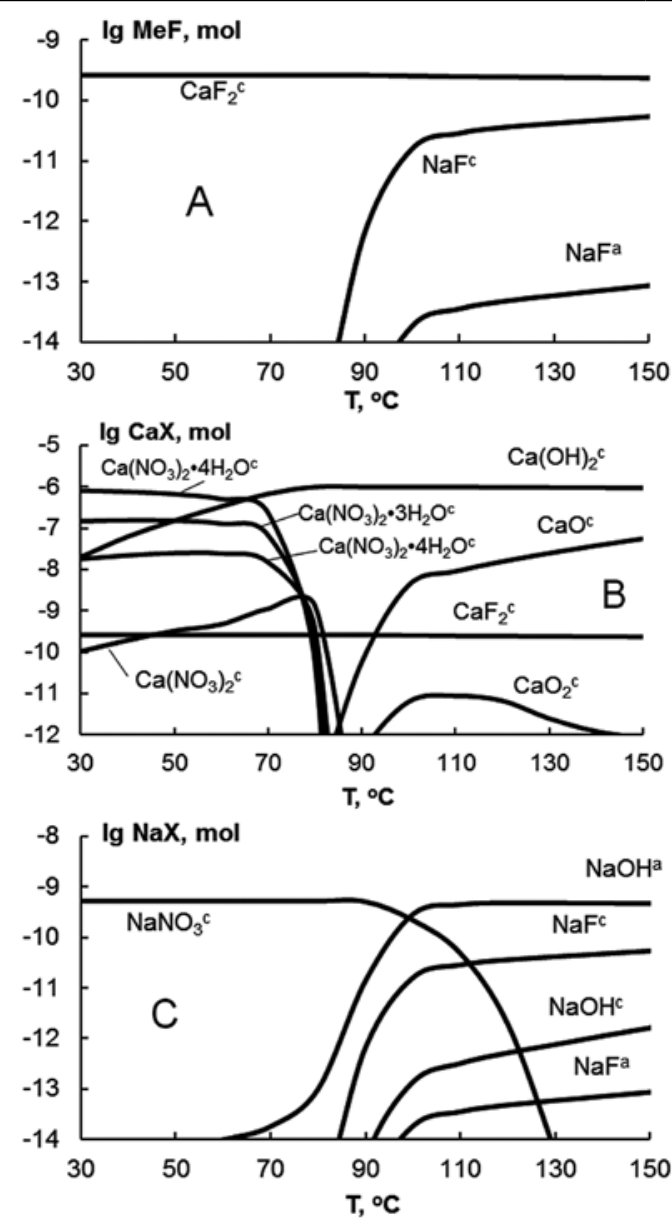

Fig. 1. Calculated functions of logarithms for the amounts of individual compounds containing fluorine $\operatorname{MeF}(A)$, calcium $\mathrm{CaX}(B)$ and sodium $\mathrm{NaX}(C)$ from the temperature of the drying sample $T$ using the experimental data of [8] ature decomposition of crystalline calcium nitrate (Fig. $1, B$ ) due to the hydrolysis, the formation of $\mathrm{Ca}(\mathrm{OH})_{2}{ }^{\mathrm{c}}$ is thermodynamically possible.

Calculated functions according to the experimental data of $[9,10]$ showed a similar composition of the final products for the drying stage at temperatures above $100^{\circ} \mathrm{C}$.

\section{The stage of pyrolysis}

Input amounts of condensed substances of this subsystem are defined by the results of calculations at the drying step at temperatures of $120^{\circ} \mathrm{C}$ [8], $140{ }^{\circ} \mathrm{C}$ [9] and $110{ }^{\circ} \mathrm{C}$ [10], which correspond to the experimental temperatures of the drying stage. Amount of argon for each zone of "thick" sample was set according to the molar ratio of $A r$ : matrix $=2 \cdot 3 \cdot 10^{3}$. The results of calculation of the equilibrium composition for the subsystems [8] are shown in Fig. 2.

According to calculations (Fig. 2, $B$ ) in the zone of sample surface and already at the initial stage of pyrolysis, the decomposition of $\mathrm{Ca}(\mathrm{OH})_{2}{ }^{\mathrm{c}}$ to a stable over a wide temperature range $\mathrm{CaO}^{c}$ will occur. Fluoride is present in the subsystem after the drying stage mostly in $\mathrm{CaF}_{2}{ }^{\mathrm{c}}$ and partly in $\mathrm{NaF}^{\mathrm{c}}$. During the pyrolysis stage it can be redistributed between these individual substances (Fig. 2, A). However, such small amounts of calcium fluoride and sodium fluoride remain in dilute condensed solution based on $\mathrm{CaO}^{c}$. Small losses of fluoride in the gas phase in the form of $\mathrm{NaF}^{\mathrm{g}}$ at the temperature range $800-1000^{\circ} \mathrm{C}$ are possible. Significant losses of fluorine 

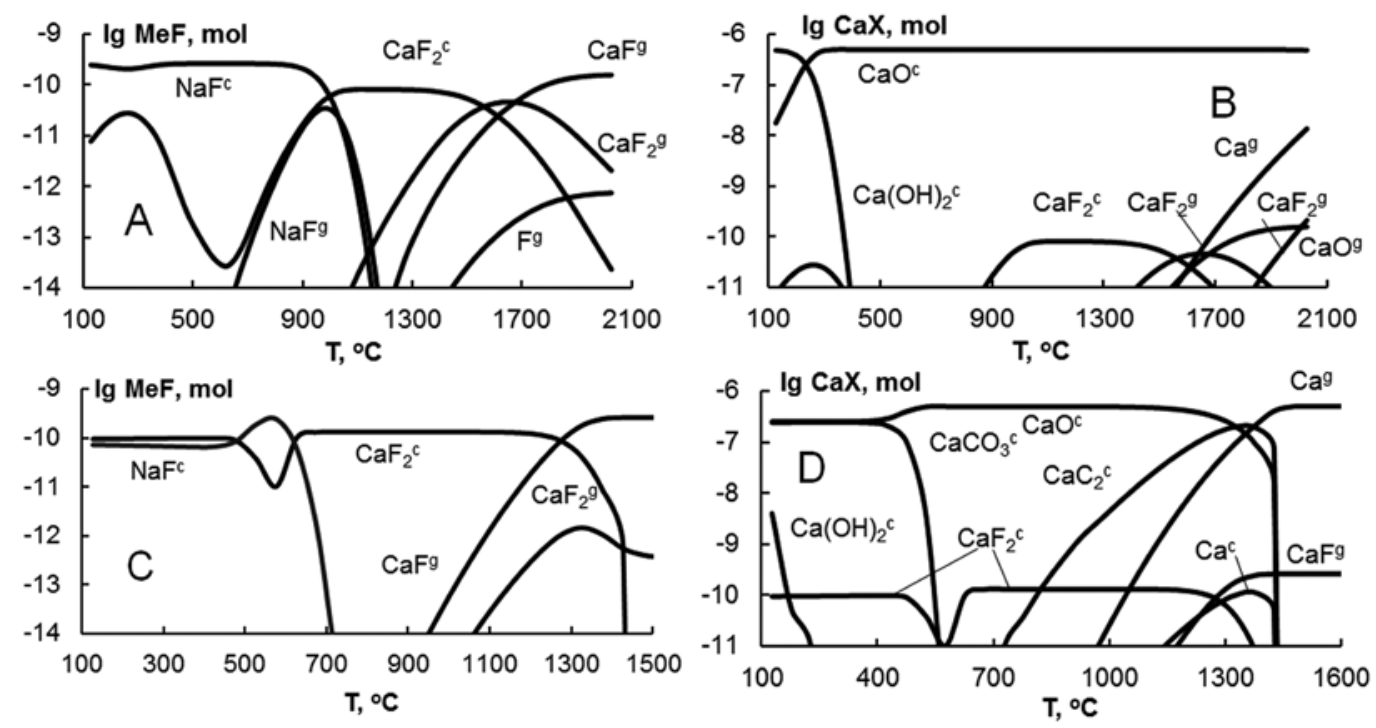

Fig. 2. Calculated functions of logarithms of amounts of individual substances containing fluorine $\operatorname{MeF}(A, C)$ and calcium $\mathrm{CaX}(B, D)$, from the temperature of pyrolysis stage $\mathrm{T}$ for the zone of sample surface $(A, B)$ and the zone of contact sample with the carbon atomizer $(C, D)$. Calculations were carried out according to the experimental data [8]

should be observed at temperatures above $1300^{\circ} \mathrm{C}$ in the form of $\mathrm{CaF}^{\mathrm{g}}$ and $\mathrm{CaF}_{2} \mathrm{~g}$.

In the zone of sample contact with the surface of the atomizer (Fig. 2, D) already at the initial temperatures of the pyrolysis stage the interaction of calcium compounds with the carbon surface atomizer to form $\mathrm{CaCO}_{3 \mathrm{c}}$, which decomposes to $\mathrm{CaO}^{\circ}$ at $500-550^{\circ} \mathrm{C}$, is thermodynamically possible. This is confirmed by experimental data [12]. Fluoride is present in the subsystem at the pyrolysis stage predominantly as $\mathrm{CaF}_{2}{ }^{\mathrm{c}}$ and partly as $\mathrm{NaF}^{\mathrm{c}}$, which remains in the diluted solution based on $\mathrm{CaO}^{c}$. Significant losses of fluoride in the gas phase of the graphite furnace should occur above 1200 ${ }^{\circ} \mathrm{C}$ in the form of $\mathrm{CaF}^{\mathrm{g}}$.

Calculations based on experimental data $[9,10]$ have shown a similar chemical composition and possible thermochemical processes for the zone of the sample surface and for the zone of the contact sample with the carbon atomizer.

Normalized calculated curves of the pyrolysis were derived using Fig. 2 calculated chemical compositions curves. These normalized curves correspond to the grade of fluorine loss in the gaseous form with an increase of the atomizer temperature (Fig. 3), and are close enough to confirm the experimental temperatures of the pyrolysis stage $\left(700^{\circ} \mathrm{C}\right.$ [8], $900^{\circ} \mathrm{C}$ [9] and $\left.725^{\circ} \mathrm{C}[10]\right)$. There is some difference in the course of the experimental and theoretical curves of the pyrolysis because the experimental curves of these three authors [8-10], obtained in similar operational conditions, have significant differences among each other. Nonetheless, all experimental and theoretical data coincide with the temperature of the pyrolysis stage.

\section{The stage of vaporization and formation molecules}

In the case of molecules $\mathrm{CaF}^{g}$ formation, input amounts of condensed substances of this subsystem for the vaporization stage were set based on the results of calculations of the pyrolysis stage (Fig. 3) at a temperature of $827^{\circ} \mathrm{C}$. The calculation results of the subsystems' chemical composition based on the experimental data of different authors for a "thin" layer of the sample interacting with carbon atomizer (tenfold molar excess) are shown at Fig. 4. Based on this data, the composition of the gas phase of the furnace, defined with the transition
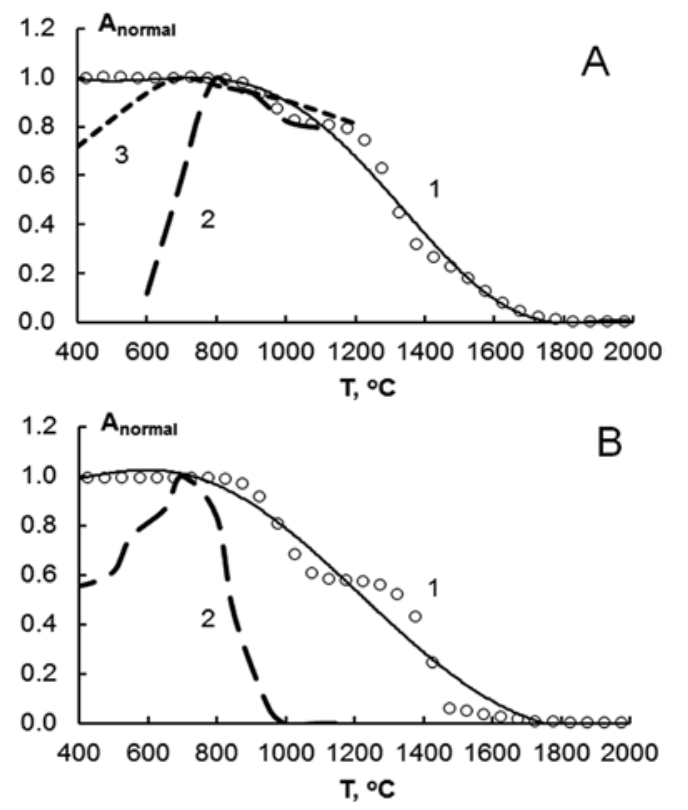

Fig. 3 Comparison of normalized experimental and theoretical curves of the pyrolysis stage: A - experimental data [9] (2) and [8] (3), theoretical calculation based on these data (1), B - experimental data [10] (2) and the theoretical calculation based on these data (1); ○-calculated points, --- - approximation 

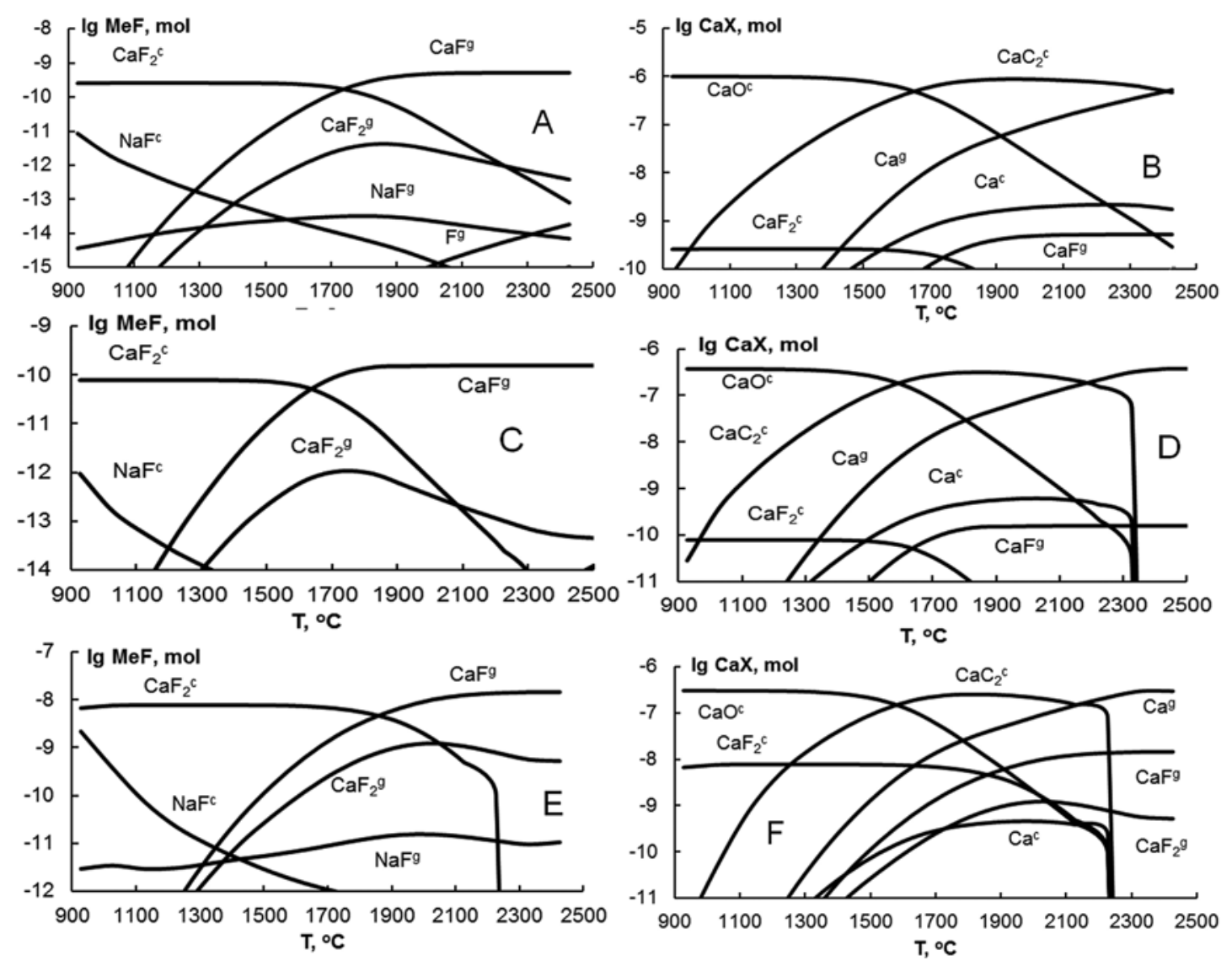

Fig. 4. Calculated functions of the logarithms of the amounts of the individual compounds containing fluorine $\operatorname{MeF}(A, C$, $E)$ and calcium $\mathrm{CaX}(B, D, F)$ from the temperature vaporization stage $\mathrm{T}$ for experimental data of: $A, B-[8] ; C, D-[9]$; $E, F-[10]$. Model of "thin" layer that interacts with the carbon atomizer

of sample components during vaporization $\left(\mathrm{C}^{g}, \mathrm{CO}^{9}\right.$, $\mathrm{Ca}^{\mathrm{g}}, \mathrm{CaF}^{\mathrm{g}}, \mathrm{CaF}_{2}^{\mathrm{g}}, \mathrm{Na}^{\mathrm{g}}, \mathrm{NaF}^{\mathrm{g}}$ ), impurity composition of argon and carbon vapors at appropriate temperature was determined. On this basis, we calculated curves of efficiency of molecules $\mathrm{CaF}$ formation and compared them with the experimental data (Fig. 5). There is a close agreement between the experimental and calculated curves. High temperature reduction of values $\eta(\mathrm{CaF})$ is due to a loss of vapor from the analytical zone of the graphite furnace as a result of diffusion and convection, which is not included in the thermodynamic calculations.

Fig. 4 shows that formation of molecules $\mathrm{CaF}^{\mathrm{g}}$, used for the molecular absorption determination of fluorine, occurs by the thermal decomposition of $\mathrm{CaF}_{2}{ }^{\mathrm{c}}$ on the surface of the graphite heater.

Using the model of a "thin" layer that interacts with the carbon atomizer, a theoretical calculation of the calibration dependence on experimental data [8] with the introduction of various amounts of fluorine as $\mathrm{NaF}$ and $40 \mathrm{mg}$ of calcium as calcium nitrate (Fig. 6) was carried out. There is a very good agreement between the experimental and theoretical normalized calibration curves.

\section{Conclusions}

By method of thermodynamic simulation the mechanism of gaseous molecules formation using a previously developed algorithm for $\mathrm{SrF}^{g}$ was defined for $\mathrm{CaF}^{g}$. It was shown that the formation of gaseous molecules
$\mathrm{CaF}^{\mathrm{g}}$ is due to the decomposition of condensed $\mathrm{CaF}_{2}{ }^{\mathrm{c}}$ during the vaporization. The mechanisms of formation $\mathrm{SrF}^{\mathrm{g}}$ and $\mathrm{CaF}^{\mathrm{g}}$ in the graphite furnace for electrothermal molecular absorption determination fluorine are similar.

The proposed algorithm can be used to study the formation mechanisms of diatomic molecules of halogen, phosphorus and sulfur for the purpose of optimizing the determination of these elements by electrothermal molecular absorption spectrometry.

\section{Acknowledgements}

This research project has been supported by UrFU under the Framework Program of Development of UrFU through the «Young scientists UrFU» competition.

\section{References}

1. Butcher D.J. Molecular absorption spectrometry in flames and furnaces. Analytica Chimica Acta, 2013, vol. 804, pp. 1-15. doi: 10.1016/j.aca.2013.07.056.

2. Ozbek N., Akman S. Molecule formation mechanisms of strontium mono fluoride in high-resolution continuum source electrothermal atomic absorption spectrometry. Analytical Sciences, 2013, vol. 29, pp. 741-746. doi: 10.2116/analsci.29.741. 3. Zaitceva P.V., Pupyshev A.A., Kurmachev lu.A. [Mechanism of molecule SrF formation in determination of fluoride by electrothermal molecular absorption spectrometry], Analitika i kontrol' [Analytics and Control], 2014, vol. 18, no. 3, pp. 287301 (in Russian).

4. Pupyshev A.A. [Acting mechanism of inorganic chemicals modifiers in electrothermal atomic absorption spectrometry]. 

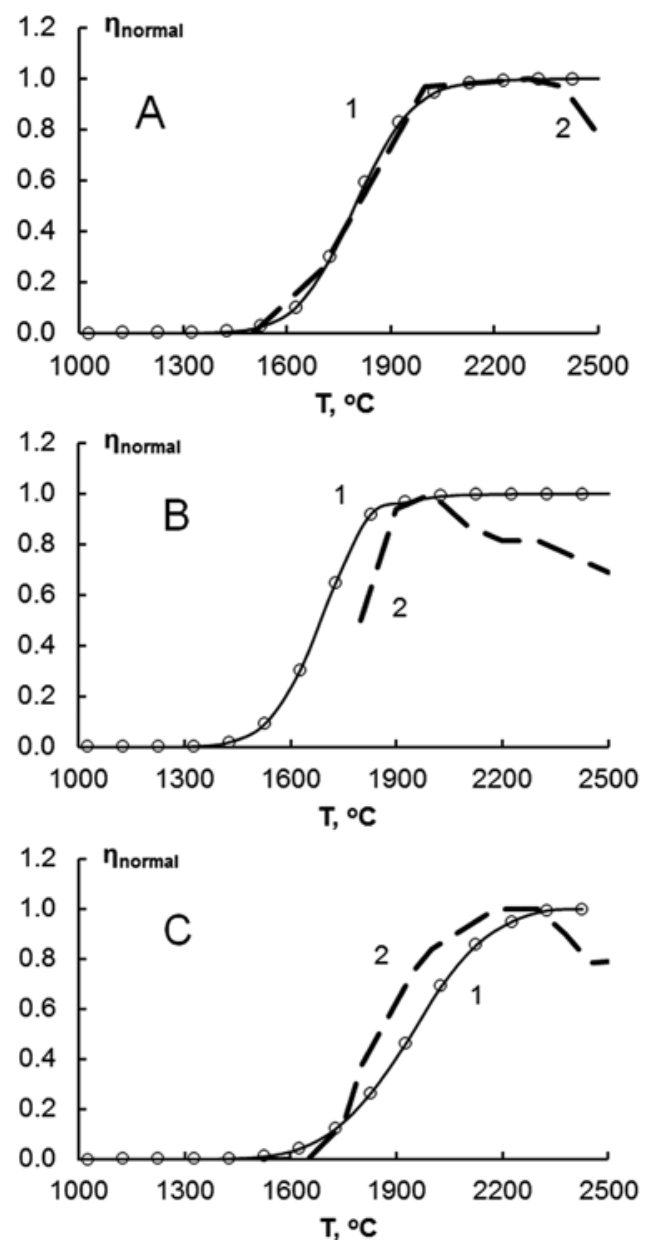

Fig. 5. Comparison of normalized theoretical (1) and experimental (2) temperature dependence of the formation effectiveness's of gaseous calcium fluoride $\eta(\mathrm{CaF})$ in analytical zone of the graphite furnace according to data: $A-$ [8]; $B-$ [9]; $C-$ [10]. Calculation model of "thin" layer that interacts with the carbon atomizer

Ukrainskii himicheskii zhurnal [Ukrainian Chemistry Journal], 2005, vol. 71, no. 9, pp. 17-25 (in Russian).

5. Pupyshev A.A. Atomno-absorbtsionnyi spektral'nyi analiz [Atomic absorption spectral analysis]. Moscow, Tekhnosfera Publ., 2009. 784 p. (in Russian).

6. Ozbek N., Akman S. Method development for the determination of fluorine in water samples via the molecular absorption of strontium monofluoride formed in an electrothermal atomizer. Spectrochimica Acta. Part B, 2012, vol. 69, pp. 32-37. doi: 10.1016/j.sab.2012.03.003.

7. Ozbek N., Akman S. Determination of fluorine in milk samples via calcium-monofluoride by electrothermal molecular absorption spectrometry. Food Chemistry, 2013, vol. 138, pp. 650-654. doi: 10.1016/j.foodchem.2012.11.008.

8. Borges A.R., Francois L.L., Welz B., Carasek E., Vale M.G.R. Determination of fluorine in plant materials via calcium monofluoride using high-resolution graphite furnace molecular absorption spectrometry with direct solid sample introduction. Journal of Analytical Atomic Spectrometry, 2014, vol. 29, pp. 1564-1569. doi: 10.1039/C4JA00067F.

9. Mores S., Monteiro G.C., Santos F.S., Carasek E., Welz B. Determination of fluorine in tea using high-resolution molecular absorption spectrometry with electrothermal vaporization of the calcium mono-fluoride CaF. Talanta, 2011, vol. 85, pp. 2681-2685. doi: 10.1016/j.talanta.2011.08.044.



Fig. 6. Comparison of normalized theoretical (1) and experimental (2) calibration curves from the data of [8]

10. HSC Chemistry 6.0. Chemical Reaction and Equilibrium Software with Extensive Thermochemical Database and Flowsheet Simulation. Outokumpu Research Oy Information Center, Finland. 2006.

11. Pupyshev A.A., Nagdaev V.K. Atomization of magnesium, strontium, barium and lead nitrates at the surface of graphite atomizers. Zhurnal prikladnoi spektroskopii [Journal of Applied Spectroscopy], 1982, vol. 10, no. 3, pp. 373-377 (in Russian).

\section{Литература}

1. Butcher D.J. Molecular absorption spectrometry in flames and furnaces // Analytica Chimica Acta. 2013. V. 804. P. 1-15. 2. Ozbek N., Akman S. Molecule formation mechanisms of strontium mono fluoride in high-resolution continuum source electrothermal atomic absorption spectrometry // Analytical Sciences. 2013. V. 29. P. 741-746.

3. Зайцева П.В., Пупышев А.А., Курмачев Ю.А. О механизме образования молекул SrF при электротермическом молекулярно-абсорбционном определении фтора // Аналитика и контроль. 2014. Т. 18. № 3. С. 287-301. 4. Пупышев А.А. Механизм действия неорганических химических модификаторов в электротермической атомно-абсорбционной спектрометрии // Украинский химический журнал. 2005. Т. 71, № 9. С. 17-25.

5. Пупышев А.А. Атомно-абсорбционный спектральный анализ. М.: Техносфера, 2009. 784 с.

6. Ozbek N., Akman S. Method development for the determination of fluorine in water samples via the molecular absorption of strontium monofluoride formed in an electrothermal atomizer // Spectrochimica Acta. Part B. 2012. V. 69. P. 32-37. 7. Ozbek N., Akman S. Determination of fluorine in milk samples via calcium-monofluoride by electrothermal molecular absorption spectrometry // Food Chemistry. 2013. V. 138. P. 650-654. 8 . Determination of fluorine in plant materials via calcium mono-fluoride using high-resolution graphite furnace molecular absorption spectrometry with direct solid sample introduction / A.R. Borges [et al.] // Journal of Analytical Atomic Spectrometry. 2014. V. 29. P. 1564-1569.

9. Determination of fluorine in tea using high-resolution molecular absorption spectrometry with electrothermal vaporization of the calcium mono-fluoride $\mathrm{CaF} / \mathrm{S}$. Mores [et al.] // Talanta. 2011. V. 85. P. 2681-2685.

10. HSC Chemistry 6.0. Chemical Reaction and Equilibrium Software with Extensive Thermochemical Database and Flowsheet Simulation. Outokumpu Research Oy Information Center, Finland. 2006.

11. Пупышев А.А., Нагдаев В.К. Атомизация нитратов магния, стронция, бария и свинца на поверхности графитовых // Журнал прикладной спектроскопии. 1982. Т. 10, № 3. С. 373-377. 